\title{
THEORY AND PRACTICE: between dichotomies and relations in the formation of English teachers
}

\author{
Paulo Boa Sortel \\ Nayara Stefanie Mandarino Silva²
}

\begin{abstract}
Many teachers in pre-service programs see knowledge about approaches, methods, and English teaching techniques - formulated and disseminated by specialists - as distant from reality or impossible to be developed. In order to understand better this problem, this research aims to analyze what is meant by the terms "theory" and "practice" and the possible relationships between them in the context of pre-service English teachers' development. From that point of view, it may be observed new and/or different views about how teachers are formed and how much this formation has prioritized contact with theories, practices, and their relationships. The theoretical bases are Freire ([1968] 2011), Rajagopalan (1984), Pereira (1988), Kincheloe (1997), Japiassu \& Marcondes (2001), Pennycook (2010) and Vieira-Abrahão (2010). Data was collected through semi-structured interviews (Lüdke and André, 1996; RIZZINI, 1999). The results indicate that student teachers understand these conceptions as opposites and that, in many cases, these concepts are not completed or are difficult to complete, rejecting them as a unity.
\end{abstract}

Keywords: Theory. Practice. Teacher Development.

\section{TEORIA E PRÁTICA: entre dicotomias e relações na formação de professores de inglês}

\section{RESUMO}

Os conhecimentos acerca das abordagens, métodos e técnicas de ensino de inglês, formulados e difundidos por especialistas, são tidos, por muitos professores em formação, como distantes da realidade ou impossiveis de serem desenvolvidos. Para melhor compreender esse problema, esta pesquisa tem o objetivo de analisar o que se entende pelos termos "teoria" e "prática" e as possíveis relações entre eles no contexto de formação de professores de inglês pré-serviço. Com isso, pode-se lançar novos e/ou diferentes olhares acerca de como professores são formados e o quanto essa formação tem priorizado o contato com teorias, práticas e suas

\footnotetext{
1 PhD in Applied Linguistics from PUC-SP. Professor at the Undergraduate School of Foreign Languages and Graduate School of Education at Federal University of Sergipe. Orcid iD: https://orcid.org/0000-0002-0785-5998. Email: pauloboasorte1@gmail.com

2 Undergraduate student in Language Teaching at Federal University of Sergipe. Undergraduate research fellow at the same University. Orcid iD: https://orcid.org/0000-00024713-6242. Email: nayaramandarino@hotmail.com
} 
relações. Os pressupostos teóricos são Freire ([1968] 2011), Rajagopalan (1984), Pereira (1988), Kincheloe (1997), Japiassu e Marcondes (2001), Pennycook (2010) e Vieira-Abrahão (2010). Os dados foram obtidos por meio de entrevistas semiestruturadas (LÜDKE e ANDRÉ, 1996; RIZZINI, 1999). Os resultados apontam que alunos-professores entendem esses conceitos como opostos e que, em muitos casos, não se completam ou são difíceis de se completarem, rejeitando-os como unidade.

Palavras-chave: Teoria. Prática. Formação de professores.

\section{TEORÍA Y PRÁCTICA: entre dicotomías y relaciones en la formación de profesores de inglés}

\section{RESUMEN}

Los conocimientos sobre los enfoques, métodos y técnicas de enseñanza de inglés, formulados y difundidos por especialistas, son tenidos, por muchos profesores en formación, como distantes de la realidad o imposibles de ser desarrollados. Para comprender mejor este problema, esta investigación tiene el objetivo de analizar lo que se entiende por los términos "teoría" y "práctica" y las posibles relaciones entre ellos en el contexto de formación de profesores de inglés pre-servicio. Con eso, se pueden lanzar nuevas y / o diferentes miradas acerca de cómo los profesores son formados y cuánto esa formación ha priorizado el contacto con teorías, prácticas y sus relaciones. Las bases teóricas son Freire ([1968] 2011), Rajagopalan (1984), Pereira (1988), Kincheloe (1997), Japiassu y Marcondes (2001), Pennycook (2010) y Vieira-Abrahão (2010). Los datos fueron obtenidos por medio de entrevistas semiestructuradas (LÜDKE y ANDRÉ, 1996; RIZZINI, 1999). Los resultados apuntan que los alumnos-profesores entienden estos conceptos como opuestos y que, en muchos casos, no se completan o son difíciles de completar, rechazándolos como unidad.

Palabras clave: Teoría. La práctica. Formación de profesores.

\section{INTRODUCTION}

Many English teachers in formation, when participating in discussions proposed by their professors, state that most topics - theories - cannot or will not be effectively developed in the teaching contexts of which they are part - in practice. The complaint is that the pieces of knowledge concerning how to teach and how to learn English, such as language teaching approaches, methods, and techniques are distant from reality or impossible to implement, because they were elaborated, and disseminated by specialists and English teacher educators many decades ago. Thefore, they reinforce a dichotomy, that is, an opposiotional relation between theory and practice. In this sense, they are seen as different concepts that are not related. This understanding 
affects teaching practices, resulting in, among other things, lack of teachers' autonomy due to the separation in those who theorize and those who practice.

On the other hand, some authors (RAJAGOPALAN, 1984; PIMENTA \& LIMA, 2002; CANAGARAJAH, 2005), using different terms to refer to this matter, claim that theory and practice cannot be dissociated. In this sense, theory cannot exist without practice and vice versa. Therefore, they refuse the opposition between the terms. From this point of view, teachers are both theorizers and practitioners, and they are understood as responsible for reflecting and making choices, based on their knowledge and experience.

The aim of this paper is to analyze both what is understood as "theory" and "practice" and the possible relations between them in the context of the formation of pre-service English teachers. Although they are undergraduate students, the participants of this research already have experience as teachers in language institutes or basic education of the private or public system. Hence, without disputing the legitimacy of what the specialists in this topic say, we seek to gain greater understanding of the reasons why English teachers still find it difficult to associate the formation course contents with the events that take place in their teaching contexts. The data was collected through semi-structured interviews that were written down and analyzed based on writers like Pennycook (2010), Rajagopalan (1984), and Nascimento (2013). This research is characterized as a case study (YIN, 2012) because it involves the investigation of a contemporary phenomenon in a real-life context.

Initially, we situate the notions of the relationship between theory and practice under consideration on the scope of this investigation. Later, we discuss the research methodological perspectives adopted here, the data analysis procedures, the presentation of the results, some outliers on the main results, and final remarks. 


\section{THEORY, PRACTICE AND THEIR RELATION}

We begin our discussion by bringing up definitions found in a dictionary of Philosophy, in which the terms theory and practice are defined as:

\section{Theory (Fr. théorie, from Lat. and Gr. theoria)}

1. In the classical meaning of Greek philosophy, speculative knowledge, abstract, pure, that stray from the world of concrete experience, sensible. Pure knowledge with no concerns.

2. *Explanatory model of a phenomenon or set of phenomena that intends to stablish the truth about these phenomena, determine their nature. Set of hypotheses systematically organized that, through its verification, confirmation, or correction, intends to explain a determined reality. E.g.: Einstein's theory of relativity (JAPIASSU \& MARCONDES, 2001, p. 183).

[...]

Practice/Practical (Gr. praktikós, from prattein: acting, performing, doing) 1. That pertains to action. Action that men exert over things, application of knowledge in a concrete action, effective. E.g.: "practical knowledge". Empirical knowledge, knowing how do to something. E.g.: "pedagogical practice", "medical practice". The opposite of theorical, speculative.

2. Practical reason. According to Kant, we answer to the theoretical question "what can we know?" through the examination a priori of knowledge; while we answer to the practical question, "what should we do?", through the establishment of the laws of ethical action. "Everything in nature acts according to laws. There is only one rational being that is able to act stemming from the representations of laws, that is, stemming from the principles, in other words, that has will. Since that in order to derive actions from laws reason is needed, the will is not otherwise practical reason." (Kant. Metaphysics of morals) (JAPIASSU \& MARCONDES, 2001, p. 155, our translation). ${ }^{3}$

The definitions in this dictionary suggest the idea of opposition between the terms, with the possibility of theory being related to knowledge and practice to doing. The distance from concrete experiences presented in the definition of the term theory and the implementation of knowledge to a concrete action in the definition of the term practice reinforce the idea that theory and practice can be easily considered separately. Although we are aware that these terms can be understood in this way in both common sense and in the academic environment, we reject that approach here and explain the main reasons why.

\footnotetext{
3 The authors of this paper take full responsibility for the translations from Portuguese to English here presented.
} 
In one of his works entitled "What is theory?" (O que é teoria?), Pereira (1988, p. 7-8) states that the issues regarding the definition of the term theory go beyond the word in Greek's etymology. Many researchers contrast theory and practice as two different and exclusionary realities, or, at least, as the thesis and antithesis of the same process. Pereira explains that this is a remnant of the classical reasoning - which exaggerated the idea of theory as an abstraction - and of the modern science - which became attached to the experimentation of the concrete object. For this reason, the author suggests that since a unity between theory and practice was not achieved by either the classical or modern thoughts, we should not opt for either of those approaches, because they exaggerate the theoretical aspect or the solely abstract knowledge. In this sense, the question that arises is: which approach should we adopt?

In the scope of Applied Linguistics, the separation between theory and practice has been rejected for more than 30 years, as explained in Rajagopalan (1984):

The theory-practice dichotomy ghost that has been haunting the discussion concerning teaching has to be unmasked urgently. In its best facet, a theory is no more than the rationalization of practice, and rationalization, in turn, is the incarnation of theory. It is necessary to save the "pure" sense of theory, very often obscured by one of the dichotomy's consequences when it is blindly followed: identifying theory as something to which it is opposed, that is, interpreting theory as the denial of practice (RAJAGOPALAN, 1984, p. 68, our emphasis, our translation).

And, more recently, in Pennycook (2010): "this is not, then, a question of applying language theory to practice, but of understanding applied linguistics from a position in which language, theory, and practice are all practices." (PENNYCOOK, 2010, p. 16).

Despite the fact that the theory-practice dichotomy "ghost" still has not been "unmasked" in the field of teacher's formation (and, we believe, in many other formation fields), in the first excerpt, Rajagopalan provokes his readers with the very pertinent point that the contents in formation courses should be directed to the clarification of theories and practices as a unity. 
Following this reasoning, in the second excerpt, Pennycook discards the understanding of Applied Linguistics as application of language theories to practice. To him, practice is the core point of this unity. To argue that, "in practice, the theory is another" is to disregard the fact that theories are written stemming from what is observed, and that practices may be based on what has been written or discussed about them.

When we consider practice as the core of this unity, it is necessary to highlight that practice relates to action - to things that people do - and, more specifically, to what professionals do. It is a relation that does not put an end in itself but rather is part of a wider social world, while also being constituted by habits and customs present in daily life actions, in a broader sense, and by specific knowledge to the execution of these activities, in a narrower sense. There is, in this case, a combination of thinking and acting (PENNYCOOK, 2010). By expanding the concept of practice to go beyond the things we do on a daily basis, and uniting it to the concept of theory since it involves the knowledge of how something is done - Pennycook's understanding expressed here makes us question how practice is really constituted when we situate the term in the classroom. According to the author's explanation, many activities are grouped aiming at the composition of a teaching practice.

Using Rajagopalan's terms (1984), even after many years trying to "haunt the theory-practice dichotomy ghost", in the context of English teachers' formation, such dichotomy still resonates in the voices of many student teachers and professors. In Celani (2000), we find some reasons for why theory and practice are still understood as parts, which cannot complete one another. Some extension and/or formation courses, conducted in a short period of time, can render a disservice, since their proposals do not contribute to the development of teachers' critical reflection. According to the author, they do not offer support and evaluation of the practice being conducted, prioritizing only the transmission of new methods, new teaching materials or theoretical perspectives, without the establishment of a relation with the context in which the course members/teachers act. These courses 
are understood as a product - something to be consumed - however they should, in fact, work as process - continuous and long-lasting - closely related to classroom practice, offering support to new practices, critically analyzed, and adapted to the most diverse acting contexts.

The roots of the issue concerning the separation between theory and practice may be, as Kincheloe (1997) explains, related to the model in which the teacher is a consumer instead of a knowledge producer: the technicalbehaviorist model. Under this teaching perspective, the priority is the mastery and reproduction of techniques on the part of the teacher, stemming from what is produced by specialists. In this case, it is not necessary to reflect about what is done in the classroom. It is enough to simply follow the class plan or "training" offered by the institution where the teacher will act.

In "Pedagogy of the oppressed" (originally, "Pedagogia do Oprimido"), Freire ([1968] 2011) explains that the basis to overcome these models of domination, in which teachers and students are just consumers and reproducers of what the dominant class demands, is in the notion of praxis, which is constant in Karl Marx's work. Without praxis, it is impossible to overcome the contradiction of oppressor-oppressed. When people reflect and act on the world, there is what Freire calls a "critical insertion", which leads to the transformation of reality.

It is worth mentioning that, with the communicative approach, at the end of the 1970's, the teaching from theoretical basis started to be discussed with the teachers so that they would be able to choose the procedures they believed most adequate, considering students' interests and needs. Hence, "training" with predetermined procedures of the audiolingual method started to become pointless (VIEIRA-ABRAHÃO, 2010).

It is not possible to form teachers who are conscious about their role in education just by teaching them technical instrumentalization - even though there are still attempts to do that nowadays. Conceiving theory and practice as a unity, that is, praxis, means understanding teachers' formation under a critical perspective, providing teachers in formation with opportunities to 
identify themselves with the profession and to develop a closer bond with the political nature of their role as additional languages teachers.

For this reason, it is necessary to investigate conceptions of the relation between theory and practice underlying the discourse uttered by the student teachers who participate in this research. They contribute with pieces of information that are essential to construct the senses and meanings about the formation they get.

\section{RESEARCH METHODOLOGY}

This case study (YIN, 2012) deals with the participation of student teachers in a Brazilian public university. All of them are close to the completing a Letras degree in English or Portuguese and English. In order to select the participants, we examined whether they had completed the credits of Student Teaching in English and what their availability to be interviewed was. We also considered the diversity of profiles when it comes to teaching experiences; for instance, among the participants, there are teachers who work in free English language courses as well as in regular schools of both the public and private system. The selection resulted in six volunteers; two of whom were considered replacements, in case of someone terminated their participation in the research (which did not happen).

We opted to use semi-structured interviews stemming from the methodological orientations of Lüdke and André (1986) and Rizzini (1999). Over the course of the interview, we asked the participants the following questions:

- In your opinion, what is theory, what is practice, and how can they be related to each other?

- How do you evaluate your theoretical knowledge?

- How can the teachers who are not graduated in Letras teach English classes?

The interviews were recorded in audio and transcribed. All of them happened individually. 
In order to analyze the interviews, we opted to take the research questions as starting point to guide the process of reading and rereading data, and to facilitate the highlight of relevant topics that help on the identification of the student teachers' understanding of their formation. This reading and rereading process is proposed by Erickson (1986), and aims at categorizing frequent topics in the interviewees' discourse, since the attention is turned to their linguistic choices. In this sense, there is no hierarchy among the elements that compose the analytical strategy of the interviews. They correlate and interweave with each other in all of the activities that compose their presentation, analysis, and interpretation. For this reason, this research is methodologically characterized as a case study.

In the table below, we present the student teachers' profiles. We attributed fictional names to them in order to preserve their identities.

Table 1: Participanting student teachers' profiles.

\begin{tabular}{|c|c|c|c|c|}
\hline Characteristics & Ellen & Justin & Kate & Patrick \\
\hline Age group (years old) & 23 & 42 & 23 & 26 \\
\hline Elementary school & private school & public school & private school & private school \\
\hline $\begin{array}{l}\text { High school } \\
\text { completion }\end{array}$ & 2007 & 1988 & 2007 & 2004 \\
\hline $\begin{array}{c}\text { Beginning of teaching } \\
\text { activities }\end{array}$ & 2008 & 1991 & 2009 & 2006 \\
\hline $\begin{array}{c}\text { Beginning of the } \\
\text { Letras undergraduate } \\
\text { course }\end{array}$ & 2008 & 2006 & 2008 & 2007 \\
\hline $\begin{array}{c}\text { Reason of choosing } \\
\text { the Letras } \\
\text { undergraduate } \\
\text { course }\end{array}$ & $\begin{array}{l}\text { Passion for the } \\
\text { English } \\
\text { language }\end{array}$ & $\begin{array}{l}\text { Has always } \\
\text { wished to be an } \\
\text { English teacher }\end{array}$ & $\begin{array}{l}\text { Wished to be a } \\
\text { better teacher } \\
\text { than the one } \\
\text { she had in } \\
\text { elementary } \\
\text { school }\end{array}$ & $\begin{array}{c}\text { Identified } \\
\text { himself with the } \\
\text { profession when } \\
\text { he developed } \\
\text { an English class } \\
\text { while he still } \\
\text { studied } \\
\text { Engineering }\end{array}$ \\
\hline $\begin{array}{c}\text { How they learned } \\
\text { English }\end{array}$ & $\begin{array}{c}\text { Free } \\
\text { languages } \\
\text { course }\end{array}$ & $\begin{array}{c}\text { Free languages } \\
\text { course and } \\
\text { University }\end{array}$ & $\begin{array}{l}\text { Free languages } \\
\text { course }\end{array}$ & $\begin{array}{l}\text { Free languages } \\
\text { course }\end{array}$ \\
\hline
\end{tabular}

Source: Authors' elaboration. 


\section{PRESENTATION AND DISCUSSION OF THE RESULTS}

Despite the strong conclusions that theory and practice should be seen as a unity in Applied Linguistics, the student teachers interviewed, when questioned about theory, practice and their relation ("in your opinion, what is theory, what is practice, and how can they be related to each other?"), said that they understand the concepts as opposites and, that, in many cases, they do not at all or hardly complement one another, rejecting them as a unity. The answers to this question are transcribed below. We place emphasis on the reasons why interviewees understood the terms as opposites by underlining some excerpts:

Researcher: In your opinion, what is theory, what is practice and how can they be related?

Ellen: Let me think... theory? Content... content that you acquire to put into practice. A notion of something that you will put into practice. Practice is applying theory. How can they be related? Practice is for you to see if that theory will work or not. Until then, it is very vague because, sometimes, you see that thing in theory, like, pretty tidy and perfect, and you see that, in practice, it is different. So, sometimes, I think that practice is worth more than theory. (INTERVIEW WITH ELLEN, our highlights).

Researcher: Justin, tell me what is theory, what is practice and how can they be related?

Justin: Theory is what we learn in the academy. Practice is what we live out of it. Theory and practice is you taking what you learned in the academy and putting it together with the practice outside of it, in a way that you achieve a satisfactory result. (INTERVIEW WITH JUSTIN, our highlight)

Researcher: What's theory for you? And... what is practice and how can they be related?

Kate: Hm... theory is what many people have, is what many people have access to, and it is what most people attached themselves to. Practice improves with theory, but it is something that many people think they have and that many people try to have, but is harder to get because, if you have never given an English class, many times you do not get to really teach the class in an English course. [...] I think that people should give more chances to practice and, because, if they read that much and know how to be a teacher, why don't they put it into practice? Why just get attached to theory and write, write, write... instead of trying to practice something that you defend. I think that this is basically it. (INTERVIEW WITH KATE, our highlight).

Researcher: Can you tell me what is theory, what is practice and how can they be related?

Revista Exitus, Santarém/PA, Vol. 9, № 4, p. 720 - 745, Out/Dez 2019. 
Patrick: Theory would be a discussion of topics, of the best way of giving a class to teenagers, the best way of giving a class to adults; and in practice, practice is not always well related to theory, so you can adapt, you can think, like, this would be a good class for this age group, because, sometimes, in practice it's... it's really bad this class.

Researcher: How can you relate them?

Patrick: Hm...l've had something kind of like a lab, that was in a private school where I teach classes, it was right when I started to do Letras, I was trying to apply theory I saw in the university, trying to get one theory right and all, then I did this correlation between theory and practice, I knew what I could do, what it was possible for me to do (INTERVIEW WITH PATRICK, our highlights).

The points of view in resonance demonstrate the excess of abstraction versus the experimentation of the concrete object that Pereira (1988) addresses, namely, understanding theories like discussions, contents, and topics that need to be put into practice. It is necessary to apply them, to take them to different environments, and these are not easily achievable tasks. If student teachers see the relation between theory and practice as difficult or vague, this may indicate distance from experiences of theory and practice as a unity in the university itself.

The way the curriculum of the Letras course in which the participants study is organized may be an indicator of this non-relation/non-unity between theory and practice. The student teacher Patrick complained, throughout the interview, that learning English and learning how to teach the language does not permeate the whole course. We reaffirm this point, based on Nascimento (2013), who analyzed the Pedagogical Project of the Letras course in which the participants study. Three issues pointed out by the author can justify the highlights put in the excerpts of the interviews. The first one is that English language classes are predominantly theoretical: 45 hours are reserved to theoretical activities while 15 hours are reserved to practical ones. Such activities, according to the Pedagogical Project analyzed, are not about practicing how to teach the language, but practicing the language itself. The table below reproduces the workload distribution of English language classes: 
Table 2: Workload distribution of English language classes

\begin{tabular}{|l|c|c|c|c|}
\hline \multirow{2}{*}{\multicolumn{1}{c|}{ Class }} & \multirow{2}{*}{$\begin{array}{c}\text { Number of } \\
\text { credits }\end{array}$} & Theory & Practice & Total \\
\cline { 3 - 5 } & & 45 & 15 & 60 \\
\hline English language I & 04 & 45 & 15 & 60 \\
\hline English language II & 04 & 45 & 15 & 60 \\
\hline English language III & 04 & 45 & 15 & 60 \\
\hline English language IV & 04 & 45 & 15 & 60 \\
\hline English language V & 04 & 45 & 15 & 60 \\
\hline English language VI & 04 & 45 & 15 & 60 \\
\hline English language VII & 04 & 45 & 15 & 60 \\
\hline English language VIII & 04 & & & \\
\hline
\end{tabular}

Source: Nascimento (2013, p. 94).

For the single degree course, Letras English, there are 480 hours, overall, for the English language classes. When it comes to the double degree course, Letras Portuguese and English, there is no English language VIII, which reduces that total workload of these classes to 420 hours. There are small differences in the curriculum of both degree courses.

The second problem is that, in the Pedagogical Project, the separation - theory for 45 hours / practice for 15 hours - of the English language classes is adopted, that is, those who elaborated the project consider that the language classes can be divided in two moments, one to theory, and the other to practice.

The third problem, which may justify the separation of theory and practice by the student teachers interviewed, deals with the reduced number of classes dedicated to English teachers' formation. According to Nascimento (2013), the classes English Teaching Methodology I and II, and Student Teaching in English I and II, total just 300 hours, in a universe of 3.225 hours of the Letras course. We reinforce that, in the Pedagogical Project, there is no relation, interdisciplinarity or theoretical-methodological movement that encourages dialogue or realization of collaborative activities among the teachers of the English Language, Methodologies and Student Teaching classes. As pointed out by the author, the English teaching practice is considerably reduced, and this fact reinforces certain inconsistencies regarding the relation with the curricular lines to teachers' formation: 
On the project under analysis, this practice is restricted to pedagogical classes, which begin in the fifth term, that is, do not happen from the beginning of the course. It seems that there is a lack of articulation among the language classes and teachers' formation, what results not only in division, but also in the fact that, throughout the project, a formation that permeates the whole course is not considered (NASCIMENTO, 2013, p. 137, our translation).

As the curriculum is structured in such way, there is an impediment to the conception of theory and practice as a unity, as the Applied Linguists see it. Therefore, teachers are denied the opportunity of a formation process in which they identify themselves with the profession from the very beginning of the course, a moment in which student teachers should have their first contact with the reality of public schools and their routine. When the relationship between theory and practice does not permeate the course, students are not provided with the opportunity to feel a greater connection and involvement with the political character of their role as English language teachers. The student teacher Kate emphasizes, in the interview, the value she attributes to practice in detriment of theory.

Researcher: What do you think of your theoretical knowledge?

Kate: Theoretical knowledge... it is useful, but I think that it involves more practice than theory. I mean, we need much more practice than theory.

Researcher: Can you talk a little bit more about it?

Kate: Sure. I think that if you only have theory, if you are too focused on theory, you take longer to get to practice, because you get stuck with what is written there. And, I think that not even that person who wrote that does the things she wrote in real life, you know what I mean?

Researcher: Can you give examples?

Kate: For example, there is this Bernard Charlot's text that I read, which discusses teachers who observe other teachers' classes. He puts it like this: if the teacher criticizes you, don't be too worried about it; he is observing one moment of your class, he doesn't know what you did with your students before or what you do with them every day. That day may be atypical. So, it's very difficult for you to measure someone's class just by watching her once and it's done.

Researcher: So, we need to observe several times?

Kate: You have to spend more time with that class so you can see what being a teacher is. So, it involves much more practice than theory. Theory is necessary because we need to know how to give the first step, but I think practice is what polishes teachers much more. So, I think I have a good deal of theoretical knowledge, but not so much, because I think I'm not used to reading about 
teaching practice, although there were some texts that caught my attention. So, what I see in College is that there are many students who have a lot of theoretical knowledge, different from me, but that they are unemployed or too focused on reading, writing and publishing. I have never published a paper or written a thing, but I have practice, and this is what I would rather have. (INTERVIEW WITH KATE, our highlights).

Interestingly, Kate uses her theoretical knowledge, like Bernard Charlot's texts, to justify her priority to practice. We consider this an indication of the understanding of theory and practice as a unity. The priority to practice offered by the student teacher is related to what Pennycook (2010) understands as "core point of this unity", since practice is what gives us ground to writing theories, both of them justify and complete each other, that is, they unite themselves.

Another point worth mentioning in Kate's talk concerns her classmates who have a lot of theoretical knowledge: "they are worried about reading, writing and publishing, and they are not yet employed". We do not believe that the fact that they are unemployed is due to their involvement with writing papers or to their engagement in the search of theoretical knowledge. It is worth reminding that they are in pre-service educational course, aimed at student teachers that will become professionals in the future, a practice that is still rising (PERRENOUD, 2002). Kate's attitude is of a teacher involved in continuing educativon, considering that she already teaches and is worried about improving her practice.

We asked Kate and Ellen, language course teachers, how come their co-workers who do not study Letras are able to teach English classes? This question may inform participants' relation with the undergraduate course of Letras, since they perform the same role of their non-graduated co-workers. However, unlike their co-workers, the student teachers pursuit a diploma in Letras.

Researcher: How can the teachers who are not graduated in Letras teach English classes?

Kate: When I took the training to get into the course I work, in my group, there were six candidates, three of them had no idea of what teaching was. 
Researcher: Do you remember their degrees or the College they werer going to?

Kate: Hmm...yes...one of them went to Law School, but she had an advanced English level; the other worked with business and lived I don't know how many years in London, so she spoke English; and the other was graduated in... I don't really remember, but it was something else that had nothing to do with teaching. So they had a lot of English, but no sense of how teaching works, how to plan a lesson, what we need to have in the beginning, what we needs to get to the end, how to connect one part to the other. So, that they didn't really have... I think this is quite related to wanting to be a teacher without knowing what being a teacher is. I think they are risk takers (INTERVIEW WITH KATE, our highlights).

Researcher: Do you know how can the teachers who are not graduated in Letras teach English classes?

Ellen: Well... I have three classmates like this in the English course, because, in private schools, they require, at least, that you have started Letras, but not in English courses, right? But, what happens... There's always a lecture, some sort of a training for future teachers. The director of the school where I work is not graduated in Letras, he went to Marketing School, but he, since he was 17 years old, works as teacher. So he also has this thing with theory, he always gives lectures, and there are two teachers, one is Brazilian, but she has lived... she spent 10 years in United States and now she is back, and one native, but had never taught English. And, even without theory, like a college degree, they often give lectures, but you can't simply take the guy into the classroom because it's not like that. You have to know a bit about the steps of a class, of how... hm... to follow a lesson plan, to teach a grammar structure. (INTERVIEW WITH KATE, our highlights).

In our highlights, we point out to possible teachers' profiles that English courses hire. Neither do they need to be enrolled in Letras courses nor they have to have a diploma in the area. Some of them, as the participants state, can be either graduated or enrolled in another bachelor's degree courses, like Law or Marketing. The main requirement seems to be what they understand as "a good English level" and it is not necessary, as Kate mentions, to have "an idea of what teaching is", revealing the merely technical character of tasks that these English language speakers need to play in the aforementioned courses.

Vian Jr. (2011, p. 62-63) clearly expresses his concern with the devaluation of second language teachers' formation in Brazil, when he states that society seems to ignore the fact that "it is enough to have lived in England, United States, Australia or another country where English is the 
official language in order to be accepted as a "good English teacher'." When Kate says that "one was graduated in Law, but she had a good English level; the other worked with business and lived I don't know how many years in London, so she had English", she ascertains the author's concern, expressed in the excerpt below:

\begin{abstract}
Unfortunately, English teaching has become a field where a minimum contact with the language is enough to a person being considered an English teacher, rather than him or her having a diploma of formation in Letras with a major in English. [...] For the English teacher, this requirement is neglected, on one hand, by the coordinators and principals, on the other, students, parents, and community in general seem to have accepted the practice that any other teacher can fill in the English teacher's position (VIAN JR., 2011, p. 63, our translation).
\end{abstract}

The explanation for this nearly generalized acceptance of the English teacher without a Letras diploma is, perhaps, the inappropriate and inefficient formation, reported by Celani (2010). If there are teachers with diplomas in English, but do not know the language to which they were "formed", then perhaps it would be justifiable to hire teachers who know the language, but do not have a diploma. The point is investing in English teachers' formation in universities, taking the syllabuses - which are in the ideal conditions - to reality (GIMENEZ, 2009, p. 43), so that teachers can be formed, and not "trained", and might be able to occupy the positions that are ascribed to them.

\title{
OUTLIERS: THE ORIGIN OF THE STUDENT TEACHERS' KNOWLEDGE
}

Before we make our final remarks, we consider of the utmost importance to highlight what we take as the outliers of this investigation, that is to say, the origin of the student teachers' knowledge. We decided to do so because the participating student teachers are enrolled in a pre-service teacher education program, but, contradictorily, they are already experienced teachers. So, where do their knowledge come from?

The knowledge that contribute to Ellen's representations on theory and practice, for instance, may come, first and foremost, from her teaching 
experience. It is common for teachers to face this reality check when they notice differences between what they study in College and what happenes in the classroom (TARDIF, 2002). We highlight two excerpts from her interview. The first one is about the fact that she does not believe that courses like English Teaching Methodology and Student Teaching would help in her formation as a teacher:

Researcher: How do you see your theoretical knowledge?
Ellen: So, I see, like, actually, I studied a lot of Languages and
Literature rather than Student Teaching and Teaching
Methodologies, but, when it comes to, I think... I do my own
research, self-study, and I don't count on the University for that.
Researcher: Can you talk a little bit more about it?
Ellen: Yeah, when I need to get my students involved, teaching funny
classes, and when I want students to go back home, like, "wow, I
learned something today". So, I think this is something I need to do
in the classroom. That's why I do self-study, I do my own research.
Here in College, things could be much better concerning teaching
tips, you know. That's why I need to do more research on how to
teach (INTERVIEW WITH ELLEN, our highlights).

When mentioning that she studies "a lot of Languages and Literature rather than Student Teaching and Teaching Methodologies", Ellen seems to claim improvement in the relation between theory and practice - that may be essential for her formation as an English Teacher. Since this relation seems to be questionable, she looks for it on her own, doing what she calls "selfstudy". Learning to teach and the subjects studied in College do not seem to be linked, as Gimenez (2012) puts it. Student teaching would be better understood as a way of "reshaping teaching objectives, accompanied by the need to rethink the way we conceive the very articulation between the various activities that make up the undergraduate course" (GIMENEZES, 2012, p. 22, our translation).

In the second interview with Ellen, she mentions the tasks she likes to assign to her students, making it clear that there is knowledge from experience, which has been integrated into her practice: your students? 
Ellen: There are two things I like. Very much. One is role playing. I love to do things like that, dynamic, playful, like, sort of, break the ice or when students create stories. Sometimes I take an object, like, an object I have to have them create a story, and they have to add that object into the story. And cookery class. I love it, I love it, I love it, I love it ... and I think they get more motivated too.

Researcher: Why do you love it so much?

Ellen: It's fun! Besides teaching the language, you are teaching them something extra, for example, a cake recipe. We've baked a cake, biscuits, we made souvenirs for Mothers' day, and so on. (INTERVIEW WITH ELLEN).

The various activities that Ellen enthusiastically said to "love" doing with her students come from the her own teaching experience. According to Tardif (2002, p. 51, our translation), "fundamental experience tends to turn into a personal way of teaching in terms of the profession, in habitus, in traits of the professional personality". This means that Ellen's day-to-day practice with her students has given her the experiential skills of teaching English through classes she finds fun, such as storytelling, cooking classes, and games.

In their everyday practice, teachers develop their own knowledge, based on their routine as well as the knowledge of their specific context. Tardif explains that this knowledge "emerges from experience and is validated by it. They incorporate individual and collective experience in the form of a set of skills, habitus, know-how to do, and know-how to be" (TARDIF, 2002 , p. 39). The author also states that this knowledge is not systematized in theories, they are a set of representations from which teachers interpret, understand, and guide their work and their routine. They are grounded knowledge in a context of multiple and conditioning interactions for teacher agency.

In Kate's interview, we identify the professional and/or pedagogical knowledge, which might be evident in the following excerpt, when we request further explanation concerning the subjects that help in her formation as an English Teacher: 
Kate: So, although English Teaching Methodology is not necessarily a practical course, it is sort of, like, theoretical, my professor was able to transform it into practice.

Researcher: Do you remember how she did that?

Kate: She asked us to do micro-teaching, as she called it. So, as much as we were sure about how to teach that class, we would have another classmates teaching another class from the same method, you know what I mean? So we could compare, debate, see how it worked, adapt, know if that method would serve our context and sO on (INTERVIEW WITH KATE).

The professional and/or pedagogical knowledge, from Tardif's viewpoint, are those found in courses at University departments, especially the ones related to Education, Teaching and the Teaching of specific subjects/ disciplines. This aspect may be evident in Kate's speech, stating that "as much as we were sure about how to teach that class, we would have other classmates teaching another class from the same method". Thus, she emphasizes the contributions of the English Teaching Methodology course, through which she had the opportunity to get in contact with various possibilities of teaching English.

In Justin's interview, we identify the curricular knowledge. That knowledge seems to be appropriated along his career, through the incorporation of contents, objectives and methods chosen and applied by his school. In the excerpt below, in which he tells how his classes are planned, there are examples of this knowledge:

Researcher: Tell me how you plan your lessons.

Justin: Well, I plan this way: I check up on the class, right? I sit down, I get the material I have available or that they have provided me, they usually do not provide anything, so I teach with what I have, some textbooks I've earned, I see what the publisher proposes, adding a few things, I distribute the workload and the content, so I take into account the schedule, the syllabus that the school follows, the objectives, methodology and such ... I take the class into account, I take the things I have with me into account... it's ... the environment as a whole (INTERVIEW WITH JUSTIN).

Curricular knowledge is as comprehensive as professional and/or pedagogical knowledge. In Justin's excerpt, he informs some of the 
objectives and methods adopted by his school, such as the ones he takes into account: "the schedule, the syllabus that the school follows, the objectives, methodology and such ... I take the class into account, I take the things I have with me into account... it's ... the environment as a whole". Curricular knowledge, in this sense, corresponds to the discourses "from which the school institution categorizes and presents the social knowledge itself defined and selected as a model of culture" (TARDIF, 2002, p. 38). It is in the exercise of their profession, and in the immersion of the daily life of the school that the teacher gets in touch with this knowledge. For the author, they present themselves concretely in the school programs, such as the objectives, contents, methods or forms of evaluation designated by the school, and that must be learned and applied by the teachers during the school year.

For English classes, according to Justin, the school rarely defines the knowledge to be transmitted as a model of culture. When Justin says, "I sit down, I get the material I have available or that they have provided me, they usually do not provide anything, so I teach with what I have, some textbooks I've earned", he informs that the selection of curricular knowledge is up to himself, and the school is only available to provide models of lesson plans and, at times, some school supplies.

Like Kate, Patrick seems to understand that the basis of his formation as an English Teacher is on professional and/or pedagogical knowledge. He states that it may come from the courses, English Teaching Methodology, and Didactics at College:

Researcher: What courses do you consider to have helped in your fromation as a teacher?

Patrick: I like ... my teaching career?

Research: Yeah.

Patrick: It's ... I think the one I liked the most was English Teaching Methodology, which ... because I saw issues that l'd missed the most, less specific ones. I really enjoyed this course.

Researcher: What did you learn from it?

Patrick: I also remember Didactics... at the time, I was reading ... the teacher assigned Dermeval Saviani and another book with several authors, an edited book. (INTERVIEW WITH PATRICK). 
Patrick seems to value both the courses related to Education in general, like Didactics, and the ones directed towards the teaching of English, in particular, such as English Teaching Methodology. In this sense, pedagogical knowledge seems to have helped Patrick to see, in a critical way, the need to be involved in courses that would lead him not only to learn how to teach, but also to understand aspects of educating beyond the teaching of grammar rules and language skills.

\section{FINAL REMARKS}

In the participants' conceptions, theory and practice are not understood as a unity; rather, there is a distance between these two terms. This distance is attributed to the reduced number of formation classes; to the lack of a relationship among the classes that compose the Letras course curriculum in which they are enrolled; and to the relative lack of opportunities for direct engagement with schools, such as supervised internships. For the time being, the participants understand formation as the excess of abstraction and the few experiences with the profession. This becomes clearer - and we could also say more serious - because it regards teachers who already know a classroom's routine. For the student teachers, although they know the English teaching reality, there are few opportunities to discuss it, and to be in contact with it stemming from the university.

For the participants, the "recipes" of how to teach, the lectures, and the content on "how to do" are strongly connected to English teachers' formation. This is justified by the acceptance of people who are not formed in Letras working in language courses, when they state that "they know English and they teach a nice class" because they participate in "trainings" and got tips on how to teach. Even if, in some moments, the participants remember perspectives concerning a critical formation, most of the times, they believe that if there are "ideal formulas" to learn the teacher profession, formation will take place. For this reason, there are points of view that prioritize and attribute more value to practice than to theory. In this sense, being formed as teacher means to have "practice". The justification is that teachers who "speak" the 
language and know how to teach a "good" class will be more easily hired by language courses.

At the end of this paper, we have more questions than answers when it comes to the possible ways of relating theory and practice in the formation of English language teachers in Brazil. What can professors do when Student Teaching is considered to be less important than the other disciplines - both by professors and student teachers? In some Colleges, student teaching is, in fact, classroom observation, and the future teachers do not have the opportunity to actually teach. In this research, the participating student teachers said that they miss the contact with real life. What are the possible ways of solving this problem?

Some curricula are hardly structured aiming the relationship between theory and practice, and providing students with opportunities to access reality (or reality check) that they need in order to learn the profession is really something worthwhile. Those curricula represent a concern. We believe that the National Council of Education's resolution, enacted in 2015, which increases the workload of Letras courses to 3.200 hours, is not a solution to the problem; however, it is a start in making people take the profession seriously in contexts where praxis is not prioritized.

Some questions still emerge from the results of this research: What should be done when teaching practice is put on second place in Letras courses curricula? In elaborating teaching plans and guiding discussions in classrooms of the Letras course, how do we account for the fact that there are students with and without teaching experiences enrolled in that class? How can we promote teaching in which student teachers stop looking for "ready recipes" and "tricks" and get involved with a curriculum that proposes long-term goals and that make the teachers' understanding of their teaching practices and themselves as teachers easier? How can we help put into practice the curricular lines to teachers' formation in Brazil? Is it possible to feel at ease, in the position of a professor, with the fact that there are "English teachers without a degree filling the positions of those who do have one? On 
a similar note, should we accept the fact that there are teachers who possess degrees without even speaking English?

It is necessary to be aware of the complexity of the pre-service English teaching courses in Brazilian universities, especially their most latent problems and their most urgent needs. If student teachers see the separation of theory from practice, in many cases, because of the unsuccessful search for "teaching recipes" - as we have stated in this paper - it is urgent to rethink syllabus desing in Letras courses. Having a Letras degree, as Gimenez (2009) points it, means not only to be prepared to act as a teacher, translator, reviewer, scriptwriter or cultural advisor, but also to participate in a broader political project that implies social changes.

Unfortunately, the technical and pragmatic perspectives are still the dominant ones for teachers in formation process, and they continue to be reflected in Letras course curricula of many universities. Perhaps, the proliferation of language courses contribute to the maintenance of such perspective. As Cox \& Assis-Peterson (2008) remind us, if the pedagogical projects are organized in a technical logic that corresponds to industrial capitalism, they favor the de-politicization of both teachers and their students. This is convenient to the dictatorial order established in Brazil during the 1960's to 1980's, and its ideals are still present in language courses' marketing strategies and in university curricula, which do not promote critical reflection concerning teaching. Among the problems that require further attention are the reduced workloads of Student Teaching, the lack of classes that reflect about the use of technology in the English teaching-learning process, and the need for contact with language teaching throughout the course, not only starting in the fifth term, with teachers' formation classes.

The data analysed in this paper shows that there still is a dichotomy between theory and practice in teachers' formation courses, which is reinforced by the separation of theoretical and practical classes. Encouraging the understanding of praxis requires all of the classes to be planned and developed in a way that makes students practice the theories they discuss. For instance, if the topic of a language class is the simple present 
tense, Professors may assign activities in which students have to plan a class to teach the topic. This means that praxis needs to be practiced in the university, so students can do it as public school teachers. We believe that teachers' formation goes beyond memorizing and putting methods to practice; it involves inciting critical thinking and autonomy to make decisions, based on teaching goals and students' contexts. When teaching is understood as applying activities mechanically, any English speaker can be trained to do it; that is why language courses do that. However, being a teacher requires reflecting and understanding concepts like language, learning, teaching, among others; it involves theoretical knowledge that is guided and is developed from practice.

\section{Acknowledgment}

We thank Malkie Wall for her constructive comments and feedback on the English version of this paper. We also thank CAPES for funding this research.

\section{REFERENCES}

CANAGARAJAH, S. Reclaiming the local in language policy and practice. Mahwah: Erlbaun, 2005.

CELANI, M. A. A. Perguntas ainda sem resposta na formação de professores de línguas. In: GIMENEZ, T.; MONTEIRO, M. C. G. Formação de professores de Línguas na América Latina e Transformação Social. Campinas: Pontes, 2010, p. 57-69.

CELANI, M.A.A. You've snatched a carpet from under my feet: courses and contexts as for change in in-service language teacher education. In: KOIKE, I. (Org). Selected papers from AILA 99, Tokyo. Tóquio: Waseda University Press, 2000, p. 242-257.

COX, M. I. P.; ASSIS-PETERSON, A. A. O drama do ensino de inglês na escola pública brasileira. In: ASSIS-PETERSON (Org.). Línguas estrangeiras: para além do método. Cuiabá: Editora UFMT, 2008. p. 19-54.

ERICKSON, F. Qualitative methods in research on teaching. In: WITTROCJ, M.C. (Ed.). Handbook of research on teaching. New York: Collier-Macmillan, 1986. P. 125-136. 
FREIRE, P. Pedagogia do Oprimido. São Paulo: Paz e Terra, [1968] 2011.

GIMENEZ, T. Diretrizes curriculares e a sala de aula de língua estrangeira: diálogos (im)possíveis? In: CORREA, D. A.; SALEH, P. B. (Org.). Estudos da linguagem e currículo: diálogos (im)possíveis. Ponta Grossa: Editora UEPG, 2009. p. 42-51.

GIMENEZ, T. Para além das questões linguísticas: ampliando a base de conhecimentos de professores de línguas estrangeiras In: MEDRADO, B.P. E REICHMANN, C. L. (Orgs). Projetos e Práticas na Formação de Professores de Língua Inglesa. João Pessoa: Editora UFPB, 2012.

JAPIASSÚ, H.; MARCONDES, D. Dicionário Básico de Filosofia. 3a ed. Rio de Janeiro, RJ: Jorge Zahar, 2001.

KINCHELOE, J. L. A formação do professor como compromisso político: mapeando o pós-moderno. Trad. Nize Maria Campos Pellanda. Porto Alegre, RS: Artmed, 1997.

LÜDKE, M.; ANDRÉ, M. Pesquisa em educação: abordagens qualitativas. São Paulo: EPU, 1986.

NASCIMENTO, L. N. A formação do professor de língua inglesa e a legislação. São Cristóvão: EDUFS, 2013.

PENNYCOOK, A. Language as a local practice. London: Routledge, 2010.

PEREIRA, O. O que é Teoria? 6a ed. São Paulo: Brasiliense, 1988.

PERRENOUD, P. A prática reflexiva no ofício do professor: profissionalização e razão pedagógica. Trad. Cláudia Schilling. São Paulo, SP: Editora Artmed, 2002.

PIMENTA, S. G ; LIMA, M. S. L. Estágio e Docência. 2a ed. São Paulo, SP: Cortez, 2002.

RAJAGOPALAN, K. O porquê de sintaxe no currículo de Letras. In: CELANI, M. A. A. (Org.). Ensino de Línguas. São Paulo: Educ, 1984. p.53-69.

RIZZINI, I. Pesquisando: guia de metodologias de pesquisa para programas sociais. Rio de Janeiro, RJ: Editora Universitária Santa Úrsula, 1999.

TARDIF, M. Saberes docentes e formação profissional. Translated by Francisco Pereira. 9.ed. Petrópolis: Vozes, 2002.

VIAN JR., O. A educação linguística do professor de inglês. In: SZUNDI, P. T. C.; ARAÚJO, J. C.; NICOLAIDES, C. S. SILVA, K. A. da. (Orgs.). Linguística Aplicada e Sociedade: ensino e aprendizagem de línguas no contexto brasileiro. Campinas, SP: Pontes, 2011. p. 61-76. 
VIEIRA-ABRAHÃO, M. H. A formação de professores de línguas: presente, passado e futuro. In: SILVA, K. A. (Org.). Ensinar e Aprender Línguas na

Contemporaneidade: linhas e entrelinhas. Campinas, SP: Pontes, 2010. p. 225234.

YIN, R. K. Estudo de caso: planejamento e métodos. Trad. Ana Thorell. 4. ed. Porto Alegre: Bookman, 2010.

Recebido em: 28 de novembro de 2018 Aprovado em: 16 de agosto de 2019 